\title{
“Can” You Really Make a Battery Out of That?
}

\author{
Michael A. Parkes* ${ }^{\mathrm{a}}$, Thomas Chen ${ }^{\mathrm{b}}$, Billy Wu ${ }^{\text {a.c }}$, Vladimir Yufit ${ }^{\mathrm{a}}$, and Gregory J. Offer ${ }^{\mathrm{a}, \mathrm{c}}$ \\ ${ }^{a}$ Department of Earth Science and Engineering, Imperial College London, \\ SW7 2BP, UK \\ ${ }^{\mathrm{b}}$ Department of Chemistry, Imperial College London, London, \\ SW7 2AZ, UK \\ ${ }^{\mathrm{c}}$ Department of Mechanical Engineering, Imperial College London, London, \\ SW7 2AZ, UK
}

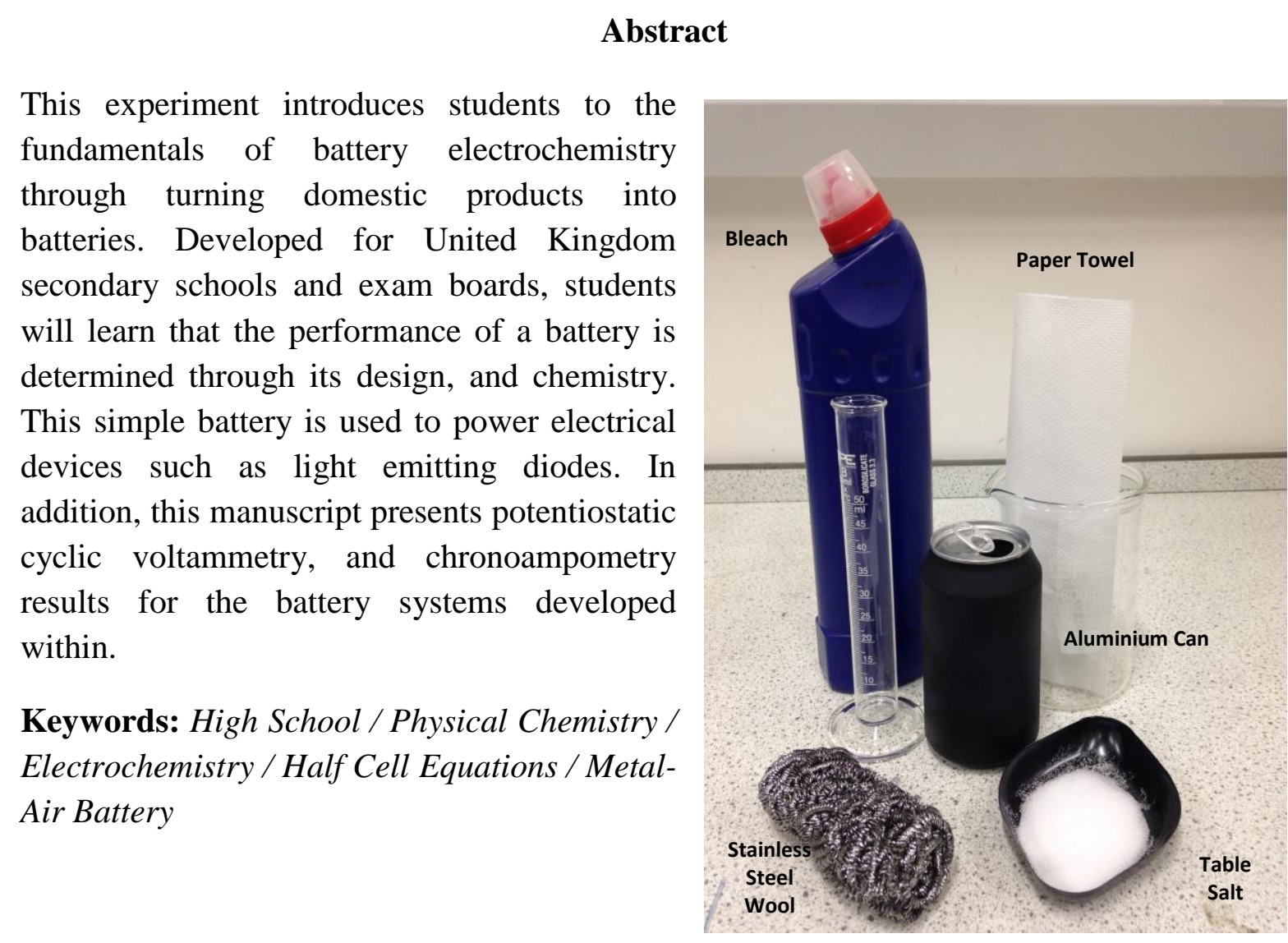

\section{Introduction}

Batteries are used in a wide range of applications including: mobile devices, hybrid and electric vehicles, and off grid electrical storage ${ }^{1}$. As battery technologies become more prevalent it will be important for future generations to understand how they work.

Experiments are a great way to inspire, and to this purpose, the electrochemistry special interest group of the Royal Society of Chemistry (RSC) has sponsored the design of a battery experiment for United Kingdom (UK) secondary schools which fulfils the requirements of the major UK exam boards general certificate of secondary education (GCSE, ages 14-16), and advanced level (A-level, ages 16-18) qualifications ${ }^{2-6}$. 
Batteries work through the controlled redox reactions of materials. Here, we develop a battery made from readily available domestic products including an aluminium drinks can. The experiment is based on previous experiments in the chemical education literature ${ }^{7-12}$ with this teaching package consolidating existing works into a simple "ready to use" guide for teachers' and students aged 14-18 to use in a 50-60 minute classroom lesson, or at home.

The performance of a battery is measured by the voltage and the current it produces. The voltage is a thermodynamic quantity determined by the chemistry. The current depends on the rate of chemical reactions, the batteries internal resistance, and the materials used in its construction; all of which can be modified through design. We present an experiment that allows students to develop an understanding of these concepts.

\section{The Experiment}

\section{Part 1 - Construction of an Aluminium Air Battery}

This section describes the construction of a battery made from products obtained from a typical supermarket. Table 1 contains the dimensions, typical chemical composition, and estimated price in GBP of the components needed to assemble the battery.

Table 1: list of components, estimated costs, dimensions, and chemicals needed to construct the battery.

\begin{tabular}{|c|c|c|c|}
\hline Component & Dimensions & Typical Chemical Composition & $\begin{array}{l}\text { Estimated Cost } \\
\text { (GBP) }\end{array}$ \\
\hline Aluminium Can ${ }^{13}$ & $330-500 \mathrm{~mL}$ & $\mathrm{Al}$ & $£ 0.75-1.00$ per can \\
\hline $\begin{array}{ll}\text { Stainless } & \text { Steel } \\
\text { Scrubber }^{13} & \end{array}$ & $20 \mathrm{~g}$ & $\begin{array}{l}\sim 12-14 \% \mathrm{Cr}, \sim 0.20-1 \% \mathrm{Mo},>2 \% \mathrm{Ni}, \\
\sim 0.1-1 \% \mathrm{C}, \sim 84 \% \mathrm{Fe}\end{array}$ & $£ 1.00$ per scrubber \\
\hline $\begin{array}{l}\text { Paper } \\
\text { Towel }^{13}\end{array}$ & $\sim 15 \times 25 \mathrm{~cm}$ & N/A & $£ 1.50$ per role \\
\hline $\begin{array}{l}\text { Domestos }{ }^{\circledR} \\
\text { Household Bleach } \\
{ }^{13}\end{array}$ & $100-300 \mathrm{~mL}$ & $\begin{array}{lcr}5 \mathrm{vol} \% & \mathrm{NaClO}, \quad<5 \mathrm{vol} \% & \mathrm{NaOH}, \\
<5 \mathrm{vol} \% & \text { Amines, } & \mathrm{C}_{12-18^{-}} \\
\text {alkyldimethyl, N-oxides } & \end{array}$ & $\begin{array}{l}£ 5.00 \text { per } 750 \mathrm{~mL} \\
\text { bottle }\end{array}$ \\
\hline $\begin{array}{l}\text { Aluminium cooking } \\
\text { foil }^{13}\end{array}$ & & $\mathrm{Al}$ & $£ 8.00$ per role \\
\hline Salt $^{13}$ & $100-300 \mathrm{~g}$ & $\mathrm{NaCl}$ & $£ 2.00$ per $750 \mathrm{~g}$ \\
\hline Sodium Hydroxide ${ }^{14}$ & $<1 \mathrm{~g}$ & $\mathrm{NaOH}$ & $£ 24.00$ per $500 \mathrm{~g}$ \\
\hline Distilled Water & $100-300 \mathrm{~mL}$ & $\mathrm{H}_{2} \mathrm{O}$ & N/A \\
\hline
\end{tabular}

It is found that battery performance can vary with the bleach used in the experiment. Some products instantaneously react with the aluminium. All experiments were carried out with Domestos® original bleach.

The battery anode is made from a $330 \mathrm{~mL}$ aluminium drinks can that is carefully prepared by removing the end with the "stay-tab ring opener" with a can opener and scissors. This exposes the internal aluminium surface, which is used in the electrochemical reactions. This is the most hazardous part of the experiment due to the sharp edges left on the can. These 
must be removed using scissors, and filed smooth using wet and dry sanding paper. Instructors may wish to prepare cans before the class.

The internal aluminium surface is cleaned and "roughened" with wet and dry sanding paper removing the protective epoxy resin layer from the inside of the can. The cathode is prepared using one $20 \mathrm{~g}$ stainless steel scrubber, typically used for kitchen cleaning. This is wrapped inside a $15 \mathrm{~cm}$ x $25 \mathrm{~cm}$ piece of paper kitchen towel. This separates the anode and cathode preventing short circuit. The stainless steel scrubber, wrapped in paper towel, is then placed inside the aluminium can, as illustrated and pictured in Figure 1.

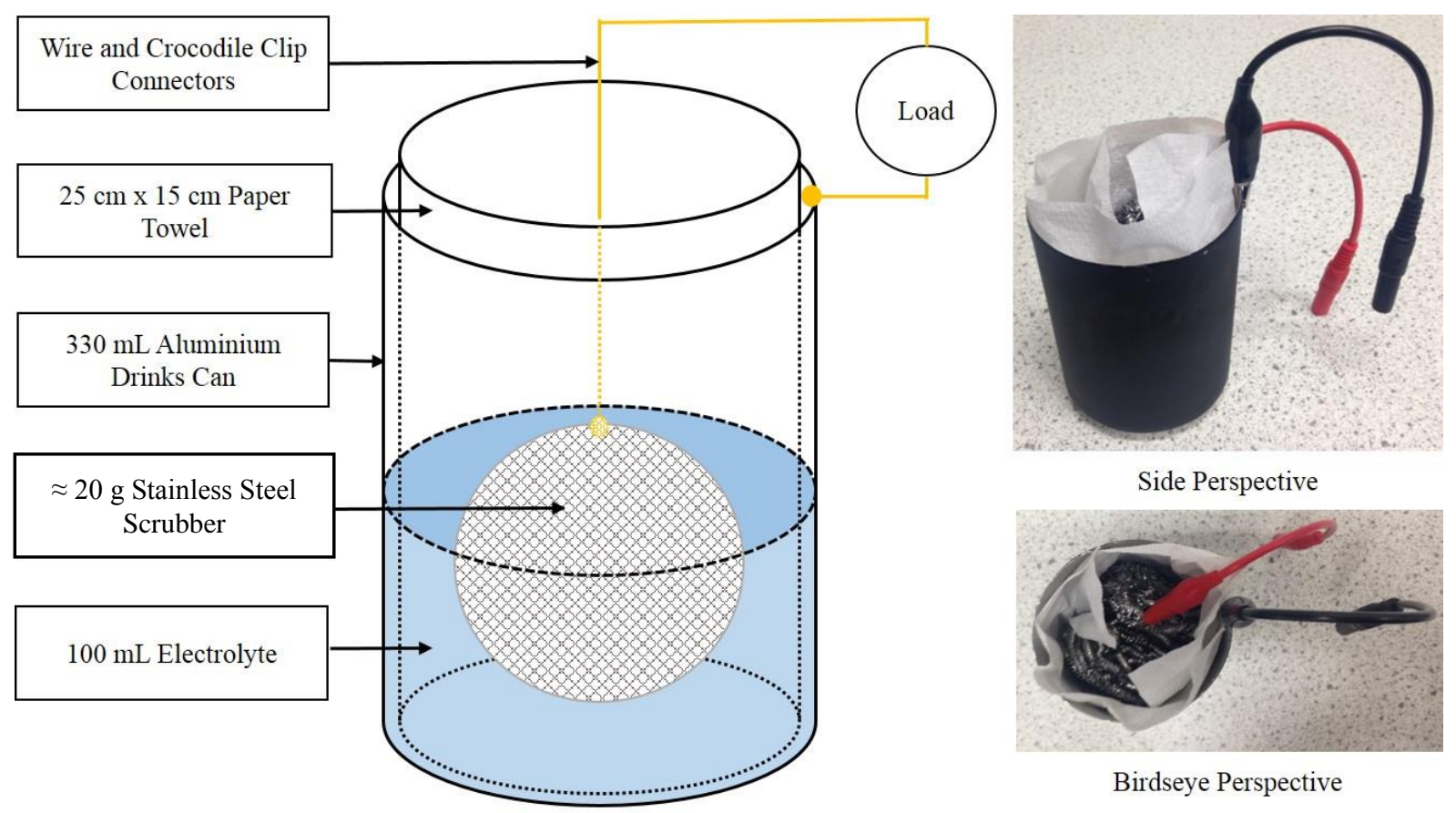

Figure 1: Schematic and pictures of an aluminium can battery made from a $330 \mathrm{~mL}$ soft drinks can.

A $100 \mathrm{~mL}$ aqueous solution of $2 \mathrm{M} \mathrm{NaCl}$ and $0.03 \mathrm{M} \mathrm{NaOH}$ is added as an electrolyte, creating an aluminium air battery. $\mathrm{NaOH}$ helps to remove the $\mathrm{Al}_{2} \mathrm{O}_{3}$ passivation layer on aluminium ${ }^{12}$, and reduces the over-potential of the oxygen reduction reaction (ORR) taking place at the cathode $^{15}$. The electrolyte is made by dissolving $\sim 11.6 \mathrm{~g}$ of $\mathrm{NaCl}$ and $\sim 0.13 \mathrm{~g}$ of $\mathrm{NaOH}$ in 100 $\mathrm{mL}$ of distilled water.

Students should determine the electrochemical half-cell equations, and the theoretical voltage $\left(\mathrm{E}^{0}\right)$ of the cell. These are outlined below in equations $1-4^{7} . \mathrm{E}^{0}$ is calculated at $2.71 \mathrm{~V}$.
Anode Reaction
$\mathrm{Al}+3 \mathrm{OH}^{-} \rightarrow \mathrm{Al}(\mathrm{OH})_{3}+3 \mathrm{e}^{-}$
$\mathrm{E}^{\mathrm{o}}=-2.31 \mathrm{~V}$
$-e q 1$
Cathode Reaction
$\mathrm{O}_{2}+2 \mathrm{H}_{2} \mathrm{O}+4 \mathrm{e}^{-} \rightarrow 4 \mathrm{OH}^{-}$
$\mathrm{E}^{\mathrm{o}}=+0.4 \mathrm{~V}$
$-e q 2$
Redox
$4 \mathrm{Al}+3 \mathrm{O}_{2}+6 \mathrm{H}_{2} \mathrm{O} \rightarrow 4 \mathrm{Al}(\mathrm{OH})_{3}$
$-e q 3$
Cell Potential
$\mathrm{E}_{\text {cell }}=\mathrm{E}_{\text {red }}-\mathrm{E}_{\mathrm{ox}}=0.4-(-2.31)=2.71 \mathrm{~V}$
$-e q 4$

Students will record the open circuit voltage $\left(\mathrm{V}_{\mathrm{oc}}\right)$ and short-circuit current $\left(\mathrm{J}_{\mathrm{sc}}\right)$ of the cell using a voltmeter and ammeter. The negative (black wire) of the voltmeter/ammeter should 
be attached to the aluminium can, while the positive (red wire) should be attached to the stainless steel scrubber. Students will measure a positive voltage and negative current. By approximating the can as a perfect cylinder or radius $\mathrm{r} \approx 3.32 \mathrm{~cm}$, the internal surface area of the aluminium anode can be calculated. This allows the current to be expressed as a current density in units of $\mathrm{mAcm}^{-2}$. Details of these calculations are provided in the Teachers' Notes. When $100 \mathrm{~cm}^{3}$ of electrolyte is added to the can, the surface area of the aluminium anode is $95 \mathrm{~cm}^{2}$. The performance of the cell is very poor. It is only possible to achieve an instantaneous $\mathrm{J}_{\mathrm{sc}}$ of $\sim 0.6 \mathrm{mAcm}^{-2}$, while the $\mathrm{V}_{\mathrm{oc}}$ is measured as $\sim 0.8 \mathrm{~V}$.

Students should explore reasons why the cell doesn't produce the theoretical voltage $\left(\mathrm{E}^{\mathrm{o}}\right)$. Some suggestions include: the parasitic side reaction of water with the aluminium (which evolves hydrogen at the anode), and the large internal resistance of the cell due to the large diffusion distances between the anode and cathode (estimated as $0.2-3 \mathrm{~cm}$ ).

\section{Part 2 - Improving Current and Voltage by Changing Cell Chemistry}

The performance of the cell can be improved by changing the chemistry. The electrolyte is replaced with $100 \mathrm{~mL}$ of house hold bleach containing 5 vol\% sodium hypochlorite $(\mathrm{NaClO})$. $\mathrm{NaClO}$ acts as an oxidising agent, providing an alternative source of hydroxyl ions. This increases the cathode potential and improves the rate of chemical reaction. The addition of table salt $(\mathrm{NaCl})$ to the bleach further improves its ionic conductivity. $\mathrm{NaCl}$ should be added to bleach in the ratio of $10 \mathrm{~g}$ of $\mathrm{NaCl}$ per $100 \mathrm{~mL}$ of bleach.

Students should re-write the half-cell equations and re-calculate $\mathrm{E}^{\mathrm{o}}$. These are outlined below in equations $5-8^{8} . \mathrm{E}^{0}$ is calculated at $3.21 \mathrm{~V}$.

$\begin{array}{lllr}\text { Anode Reaction } & \mathrm{Al}+3 \mathrm{OH}^{-} \rightarrow \mathrm{Al}(\mathrm{OH})_{3}+3 \mathrm{e}^{-} & \mathrm{E}^{\mathrm{o}}=-2.31 \mathrm{~V} & -e q 5 \\ \text { Cathode Reaction } & \mathrm{ClO}^{-}+\mathrm{H}_{2} \mathrm{O}+2 \mathrm{e}^{-} \rightarrow \mathrm{Cl}^{-}+2 \mathrm{OH}^{-} & \mathrm{E}^{\mathrm{o}}=+0.9 \mathrm{~V} & - \text { eq } 6 \\ \text { Redox } & 2 \mathrm{Al}+3 \mathrm{ClO}^{-}+3 \mathrm{H}_{2} \mathrm{O} \rightarrow 2 \mathrm{Al}(\mathrm{OH})_{3}+3 \mathrm{Cl}^{-} & & - \text {eq } 7 \\ \text { Cell Potential } & \mathrm{E}_{\text {cell }}=\mathrm{E}_{\mathrm{red}}-\mathrm{E}_{\mathrm{ox}}=0.9-(-2.31)=3.21 \mathrm{~V} & & - \text { eq } 8\end{array}$

Students will re-measure the $\mathrm{V}_{\mathrm{oc}}$ and $\mathrm{J}_{\mathrm{sc}}$ of the cell. When $100 \mathrm{~cm}^{3}$ bleach and $10 \mathrm{~g}$ of $\mathrm{NaCl}$ is added to the cell, it is possible to achieve an instantaneous $J_{\mathrm{sc}}$ of $\sim 2 \mathrm{mAcm}^{-2}$, while the $\mathrm{V}_{\mathrm{oc}}$ is measured as $\sim 1.0 \mathrm{~V}$.

\section{Part 3 - Improving Total Cell Current through Design}

The total current of the cell can be further improved by increasing the surface area of the anode. This can be achieved by rolling additional aluminium cooking foil into the can as pictured in Figure 2. A piece of $20 \mathrm{~cm}$ x $30 \mathrm{~cm}$ aluminium foil is folded in half to make a 10 $\mathrm{cm} \times 30 \mathrm{~cm}$ sheet. Aluminium cooking foil typically has a shiny side and a non shiny side. It is recommended that the foil is folded so that the non-shiny side is on the outside. A $15 \mathrm{~cm} \mathrm{x}$ $25 \mathrm{~cm}$ piece paper towel is placed on-top of the foil, so that it is in the centre, and there is 2.5 
$\mathrm{cm}$ of paper either side of the foil. This is followed by a stainless steel scrubber, and a second $15 \mathrm{~cm}$ x $30 \mathrm{~cm}$ piece paper towel. This creates a "sandwich" like structure. The "sandwich" is then rolled; with the aluminium foil forming the outer most layer. It is vitally important that the aluminium foil does not touch the stainless steel scrubber. The roll is then placed inside the can so that the aluminium foil and can make electrical contact. Wires are then connected to the can and scrubber in accordance with the diagram in Figure 1.

When an electrolyte mixture consisting of $100 \mathrm{~mL}$ of bleach and $10 \mathrm{~g}$ of $\mathrm{NaCl}$ is added, a total $\mathrm{J}_{\mathrm{sc}}$ of $\sim 450 \mathrm{~mA}$ can be achieved. This is in contrast to a total $\mathrm{J}_{\mathrm{sc}}$ of $\sim 190 \mathrm{~mA}$ measured when $100 \mathrm{~mL}$ of bleach and $10 \mathrm{~g}$ of $\mathrm{NaCl}$ is added to the cell design presented in Part 2.

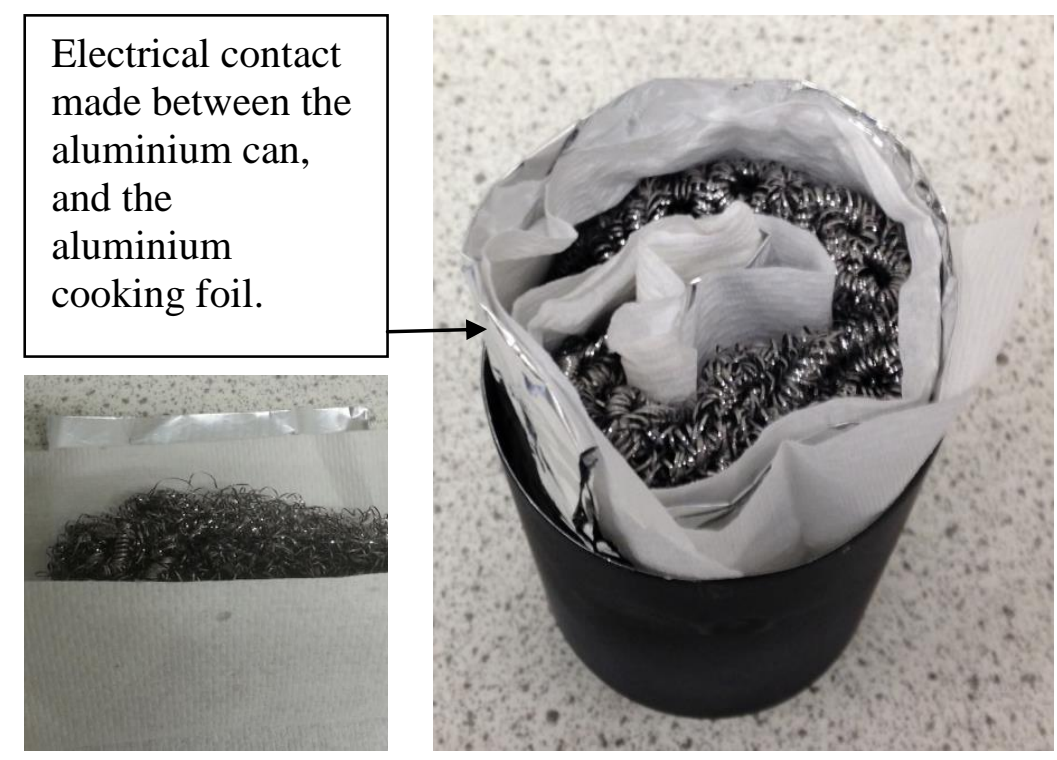

Figure 2: Bottom left: Image of the aluminium foil, paper towel, stainless steel scrubber, paper towel "sandwich", which is rolled and placed into the aluminium drinks can.

\section{Part 4 - Electrochemical Performance and Powering Light Emitting Diodes}

Different battery designs were tested using potentiostatic cyclic voltammetry (CV) and chronoamperometry. Potentiostatic CV is a technique that measures the cell current with respect to an electrode potential which varies with time. This can be used to identify the electrode potential at which the maximum current, and hence maximum power occur. A scan rate of $100 \mathrm{mVs}^{-1}$ was used to measure the current of the battery as the electrode potential was varied between $0.8 \mathrm{~V} \rightarrow 0 \mathrm{~V} \rightarrow 0.9 \mathrm{~V} \rightarrow 0.8 \mathrm{~V}$. The current was recorded every $2.5 \mathrm{mV}$ giving 40 data points per $100 \mathrm{mV}$.

The battery designs from Parts $\mathbf{2}$ and $\mathbf{3}$ were tested with an electrolyte mixture consisting of $100 \mathrm{~mL}$ of bleach and $10 \mathrm{~g}$ of $\mathrm{NaCl}$. The power of the battery is calculated by multiplying the voltage by the current. Figure 3 plots the magnitude of the average current and average power vs voltage curves for the two different designs. Full details of the experimental method can be found in the Teachers' Notes. 
Chronoampometry was used to measure the cell current at a fixed electrode potential over time. The electrode potential was fixed to $0.43 \mathrm{~V}$, which is approximately the potential at which the maximum power for the bleach battery presented in Part $\mathbf{2}$ is obtained. The current was recorded every second over $1800 \mathrm{~s}(0.5 \mathrm{hr})$. The average power and the total work done by the cell were then calculated. A full description of the chronoampometry experimental method can found in the Teachers' Notes. The average power and the total work done by the cells are recorded in Table 2.

The CV and chronoampometry results show that the design presented in Part $\mathbf{3}$ has a significantly better short circuit current and maximum power. When any two aluminium bleach-batteries are connected in series, enough voltage is produced to illuminate red or orange LEDs.
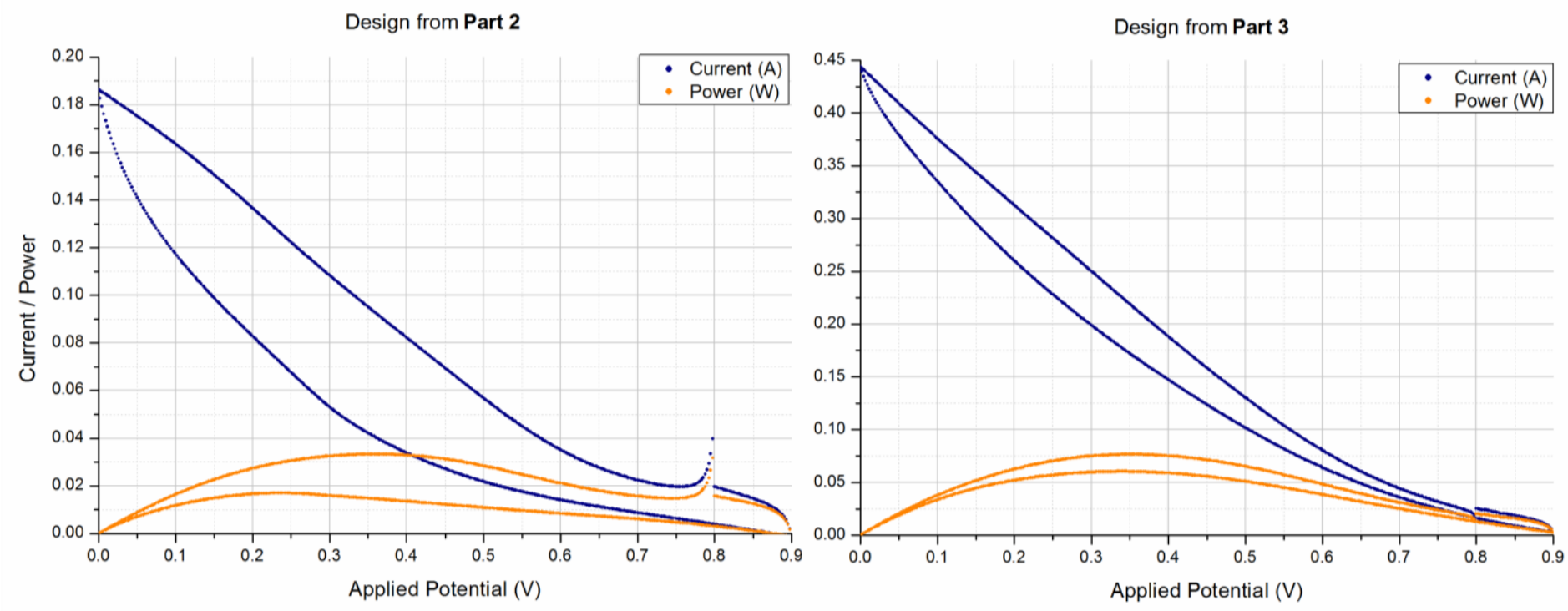

Figure 3: Average potentiostatic cyclic voltammetry, and voltage power plots of the different aluminium can battery designs. Left: battery design from Part 2 Right: battery design from Part 3

Table 2: Average power and the total energy results for two the aluminium can battery designs.

\begin{tabular}{cccc}
\hline System & $\begin{array}{c}\text { Steady State } \\
\text { Voltage (V) }\end{array}$ & $\begin{array}{c}\text { Average Cell Power } \\
(\mathbf{m W})\end{array}$ & $\begin{array}{c}\text { Total Work } \\
\text { Done }(\mathbf{J})\end{array}$ \\
\hline $\begin{array}{c}\text { Aluminium can, stainless steel } \\
\text { scrubber, paper towel, 100mL, } \\
\text { bleach, 10g salt }\end{array}$ & 0.43 & 11.6 & 21 \\
\hline $\begin{array}{c}\text { Aluminium can, stainless steel } \\
\text { scrubber, paper towel, } \\
\text { aluminium foil roll, 100mL } \\
\text { bleach, 10g salt }\end{array}$ & 0.43 & & \\
\hline
\end{tabular}




\section{Conclusion}

With a growing interest in batteries for delivering a cleaner energy future it is important to design an appropriate battery experiment for UK schools in order to inspire the next generation of scientist and engineers. To this purpose, a simple battery experiment has been designed and tested.

\section{Associated Content}

- GCSE student lab script ages 14 -16: lab script, questions, and answers, for a 1 hour classroom lesson.

- A-level student lab script ages 16-18: lab script, questions, and answers, for 2 x 1 hour classroom lessons.

- Teachers' Notes: supporting calculations, experimental setup, hazards.

- Teachers' slides: A short set of slides introducing battery chemistry.

\section{Author Information:}

Corresponding author: Michael.Parkes07@imperial.ac.uk

\section{Acknowledgements}

The authors acknowledge the Royal Society of Chemistry for funding this project.

\section{References}

(1) Mehrdad Ehsani, Yimin Gao, A. E. Modern Electric, Hybrid Electric, and Fuel Cell Vehicles: Fundamentals, Theory, and Design, Second Edition, second edi.; CRC Press, 2009.

(2) AQA. GCSE Chemistry Specifications http://www.aqa.org.uk/subjects/science/gcse/chemistry-4402 (accessed Aug 14, 2014).

(3) AQA. A-Level Chemistry Specifications http://www.aqa.org.uk/subjects/science/alevel/chemistry-2420 (accessed Aug 14, 2014).

(4) Edexcel. GCSE Chemistry Specifications http://www.edexcel.com/QUALS/GCSE/GCSELEG/SCIENCE/CHEMISTRY/Pages/default.aspx (accessed Aug 14, 2014).

(5) Edexcel. A-Level Chemistry Specifications http://www.edexcel.com/quals/gce/gce08/chemistry/Pages/default.aspx (accessed Aug $14,2014)$.

(6) OCR. A-Level Chemistry Specification http://www.ocr.org.uk/qualifications/as-alevel-gce-chemistry-a-h034-h434/ (accessed Aug 14, 2014). 
(7) Tamez, M.; Yu, J. H. Aluminum - Air Battery. J. Chem. Educ. 2007, 84 (12).

(8) Furlan, P. Y.; Krupa, T.; Naqiv, H.; Anderson, K. An Open-Ended Project: Building a High Performance, yet Simple, Household Battery. J. Chem. Educ. 2013, 90 (10), $1341-1345$.

(9) Muske, K. R.; Nigh, C. W.; Weinstein, R. D. A Lemon Cell Battery for High-Power Applications. J. Chem. Educ. 2007, 84 (4), 635.

(10) Worley, J. D.; Fournier, J. A Homemade Lemon Battery. J. Chem. Educ. 1988, 65 (2), 158.

(11) Yamana, S.; Murakami, M. An Easily Constructed Secondary Battery. J. Chem. Educ. 1984, 61 (8), 713.

(12) Battery, A.; Chasteen, S. V. The Salty Science of the Aluminium Air Battery. Phys. Teach. 2008, 46, 544-547.

(13) Amazon. Market place www.amazon.co.uk (accessed May 20, 2015).

(14) Sigma Aldrich. No Title www.sigmaaldrich.com (accessed May 20, 2015).

(15) Porbaix, M. Atlas of Electrochemical Equilibria in Aqueous Solutions; NACE International Cebelcor, 1974. 